SCOTT WURDINGER

Professor of Minnesota State University, Mankato, USA

RUDOLPH JENNIFER

Professor of Minnesota State University, Mankato, USA

\title{
TEACHING IMPORTANT LIFE SKILLS THROUGH PROJECT BASED LEARNING
}

US high schools appear to measure success according to the number of students admitted into four-year institutions each year. Although this is one measure, there are some schools that focus on developing important life skills needed to become productive members of society. Online surveys were sent out to alumni, students, teachers, and parents to a student-centered charter school in Minnesota to explore definitions of success and determine if this school teaches life skills. One hundred and forty-seven surveys were collected from these four groups. Life skills such as creativity (94\%) and ability to find information (92\%) were ranked much higher than academic skills such as test taking (33\%) and note taking (39\%). Academic skills ranked low, yet 50 percent of the alumni polled graduated from college, which is considerably higher than the national average (39\%). To further enhance the learning at project based learning schools, educators should provide opportunities for students to practice academic skills such as note taking and test taking so that students who plan to attend college will be better prepared. The research in this study showed that this school is excellent at teaching important life skills that help students succeed in college, and in life in general.

Keywords and expressions: charter schools, EdVisions, school reform, small schools
Mainstream US public high schools often measure success based on acceptance rates into post-secondary education institutions each year, while the less successful students are encouraged to pursue jobs after graduation (Bushaw, 2007). This measurement of success relies heavily on students' abilities to do well on college entrance tests, which typically require fairly high scores for admittance into undergraduate programs. Although college admittance is one way to measure high school success, other schools using innovative approaches to learning are reexamining what it means to be successful after graduating from high school. It is our assumption that schooling should be about more than academic skill development, and should focus on teaching important life skills such as creativity and problem solving that will help students become successful community members after they graduate from high school. This research study focuses on one school that has a broad view of success. Minnesota New Country School (MNCS), located in Henderson, Minnesota (50 miles southwest of

Minneapolis), uses project-based learning (PBL) as its primary teaching method. MNCS has a national reputation in the United States for designing their entire curriculum on PBL and was chosen for this study because of their emphasis on self-directed learning. MNCS's view of success is broader 
than its traditional counterpart, and attempts to teach students important life skills that are needed to be productive members of society, regardless of whether they attend college or not. In 1994 EdVisions Cooperative was created alongsideMNCS for the purpose of "creating a professional association of teacher/owners that contract with a school board to supply a learning program. It is based upon true site-based management and dynamic and flexible decision-making' (EdVisions, 2008). MNCS gained national attention in 2001 when the Bill andMelinda Gates Foundation awarded a grant to the original creators ofMNCS to replicate the school. It was at this point that EdVisions, Inc., a non-profit organization was formed to oversee the replication process. Since 2001 EdVisions, Inc. has created over 45 schools across the US modeled after its flagship school. MNCS consists of grades 6-12 (11-18-year-olds), with a total of 109 students and eight advisors and eight teaching assistants (Study of theMinnesota New Country School, n.d.). Students who attend this school are from southern Minnesota usually within a 40-mile radius. They come from wide-ranging socio-economic backgrounds. Dee Thomas, lead teacher at the school who is responsible for collecting student data on family income, mentioned that the number of students at or below poverty as defined by the state department of education has ranged from 21 to 35 percent over the past 15 years. She also mentioned that the school is situated in a "proud farming community'where parents would be embarrassed to fill out income levels and so she believes the numbers are probably closer to 50-60 percent (D. G. Thomas, personal communication, 12 December 2008). The school consists of a large open room with several pods of computer workstations. Each pod has 15-18 computer workstations, similar to what one would observe in a work environment, and each pod has one advisor. Students do much of their work at their computers, however there are several other rooms connected to the large open room where students can do specialized work such as design and build construction projects, record music, and grow plants to name a few. There is also a stage used for theater performances and project presentations. The project process consists of filling out a project proposal form, negotiating the details of the project with an advisory committee, doing the project, and presenting the project to the advisory committee. Much of the time students work alone on their own projects, primarily because of their own specific interests, however students are allowed to collaborate when they have similar interests in a project. Projects are broad ranging and have included designing museums, developing software programs, designing claymation characters, creating videos, and creating documentaries through pictures (Newell, 2003). Depending upon their complexity, these projects may take a few days or several months to complete. When students finish a project they demonstrate their level of understanding by doing a presentation for their advisory group consisting of peers, advisors, community members, and parents. After the presentation, advisors and students discuss what curriculum state standards have been met through the project, and how many credits they will receive for their work. Students must complete all of the state standards so they are provided a copy of the standards and asked to be mindful of how they will complete all the standards through their projects. Students move through this process at their own pace and finish their high school edu- 
cation when they have met all the mandatory state standards. Advisors work closely with students to make sure that all standards have been addressed through their project work. Some students graduate earlier than their traditional counterparts and others graduate later. MNCS's approach to learning is quite different than the lecture format used by many schoolteachers, because with PBL, students take control of their own learning by choosing projects that are relevant and meaningful to their own lives. The theoretical underpinnings of the project method rely heavily on Dewey's (1938) "pattern of inquiry". The pattern of inquiry consists of six steps, however Dewey's explains that his theory is similar to the scientific method and highlights four basic steps (pp. 101-19). He explains that a relevant problem (step one) causes perplexity and desire to find an answer, which is then followed by creating a plan (step two), testing the plan against reality (step three), and reflecting on its worth (step four). The planning and testing phases of this learning process are critical to project based learning. Designing and building projects require students to solve problems and test out their ideas to determine solutions. Responding to instructor questions and reciting back information, which is a common teaching method in traditional education, allow students to talk, but learning becomes inspirational and exciting when students create plans to build projects and test them against reality. Creating a website, building a learning portfolio, performing an experiment, creating a piece of artwork, or building something off a blueprint, all require students to plan and test ideas in order to determine their worth. For Dewey learning meant doing something with the subject matter aside from reciting and memorizing information. Like Dewey, MNCS's philosophy is based on students' interests and allows them to choose relevant meaningful projects that they create, design, and build (Thomas et al., 2005). Students at this school are given the freedom to determine their own projects and work at their own pace, and the advisors act as guides or facilitators of the learning process. Since this approach is highly student-centered and allows students freedom to work at their own pace, it provides opportunities to practice life skills such as time management, problem solving, and responsibility. This approach to learning has the potential to teach not only academic content, but also skills that are critical in helping young adults to become productive members of society. Much of the research conducted on PBL shows an increase in student motivation, student engagement, and academic achievement. Cornell and Clarke (1999) conducted an extensive study on standards based teaching and learning, primarily because they wanted teachers to move away from lecturing to a student-centered format where students were engaged with hands-on projects. They found that students were more engaged when involved in project based learning because it gave them an opportunity to work with other students while doing hands-on activities, which provided them with a more self-directed learning environment. This process had benefits for lower performing students because it gave them an opportunity to discover skills necessary to complete projects, and allowed them to progress at their own pace. However, two of the paradoxes they discovered, "less teacher talk requires more teacher time" and "free ranging self-directed inquiry depends on a tight design structure", indicate that even though motivation and student learning 
were enhanced through the project based learning process, it requires more work for teachers when designing projects and preparing lessons (p. 94). Teachers commented that the initial phase of the project based learning process required a fair amount of planning time; however once established, they were able to focus more on guiding students through the process. Liu and Hsiao (2002) conducted a research study on using project-based learning with middle school students and found that it increased their "learning of design knowledge, their cognitive strategy use, and their motivation toward learning” (p. 311). In this study students assumed the roles of researcher, graphic artist, programmer, project manager, and audio/visual specialist and worked together to complete multimedia presentations. Because students were directly involved in the process they were able to understand and retain the information they were using while creating and designing their multimedia

presentation. Their research clearly indicates that project based learning has the potential to enhance both student motivation and performance in the classroom. These two authors sum up their research by claiming that students showed "substantial gains in their abilities to understand, use, and present geometric concepts” (p. 303).

Wurdinger et al. (2007) conducted a year-long study that looked at teacher acceptance and student engagement, and discovered that providing a one-day staff training to educate teachers on how to use project based learning enhances and promotes teacher acceptance, which is critical to implementing and sustaining the use of this method in school settings. "Educational change depends on what teachers do and think - it's as simple and as complex as that" (Fullan, 2001: 115). Without teacher acceptance innovative methods like projectbased learning won't make it through the door of the classroom. Middle school teachers interviewed about student engagement in this study were enthusiastic about using this method and stated that it "promotes discussion and peer teaching, enhances student ownership, increases higher order thinking and life skills, and promotes group cohesiveness" (p. 157). Some teachers used individual projects and others used group projects, but in either situation teachers supported the use of this method because they observed a high level of motivation when students were engaged with their projects. Some teachers stated that students were so engrossed with their projects that they did not notice the teacher was in the room. Our research study is different than previous studies and focused on the question: does Minnesota New Country School provide students with necessary skills and knowledge to be successful after graduation? The researchers chose this question to determine if the school teaches important life skills and secondly, to determine if this educational approach lends itself to a broader definition of success aside from being accepted into post-secondary institutions. In addition the researchers wanted to explore how alumni, students, staff, and parents define success, assuming that they would have a broader definition due to school's emphasis on project-based learning. We know that many students do well enough at MNCS to get accepted into college, but because of this unusual approach to learning we wanted to take a closer look at whether students were learning valuable life skills. 


\section{LITERATURE}

1. Bushaw, W. J. (2007) From the mouths of middle-schoolers: important changes for high school and college. Phi Delta Kappan, 89(3), 189-93.

2. Cornell, N. \& Clarke, J. (1999) The cost of quality: evaluating a standards-based design project. National

4. Association for Secondary School Principals Bulletin. Online: http://www.findarticles. com/p/articles/mi_qa3696/is_199901/ai_n8835892 [accessed December 2006].

5. Dewey, J. (1938) Logic: The theory of inquiry. New York: Holt, Rinehart, and Winston.

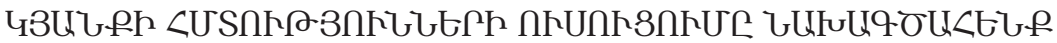

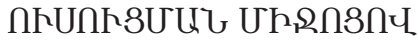

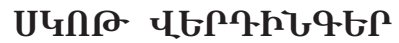

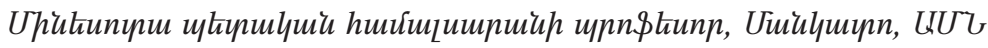

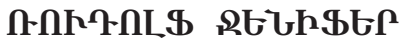

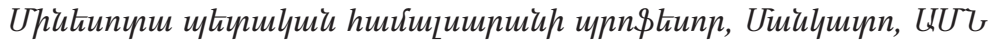

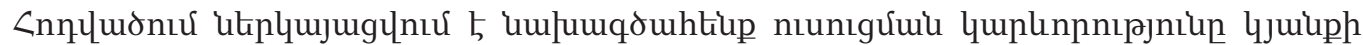

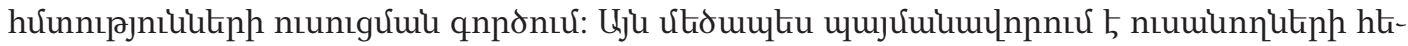

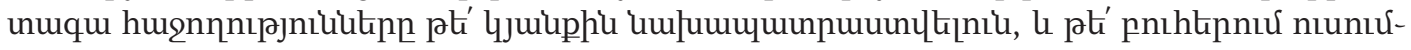
uunnıpjuil hưưup:

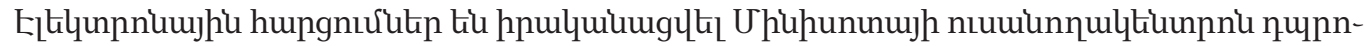

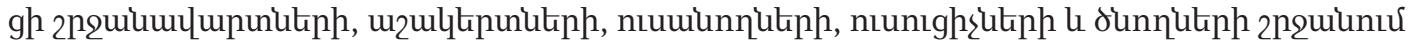

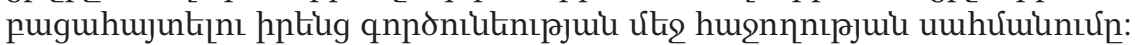

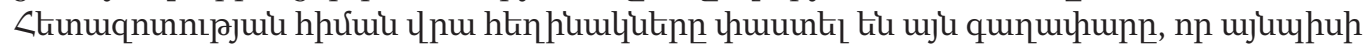

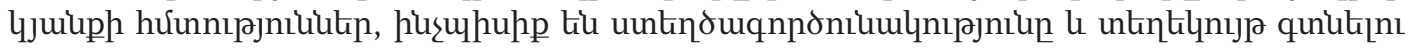

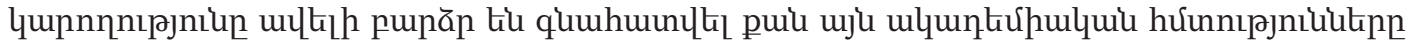

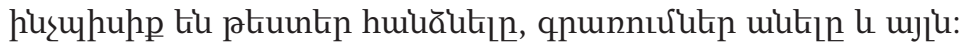

\section{ОБУЧЕНИЕ ОСНОВАМ ЖИЗНЕДЕЯТЕЛЬНОСТИ МЕТОДОМ ПРОЕКТА СКОТТ ВЮРДИНГЕР}

Профессор Миннесотского государственного университета, Манкато, США

\section{РУДОЛЬФ ДЖЕННИФЕР}

Профессор Миннесотского государственного университета, Манкато, США

В статье представлена важность метода проекта в обучении основам жизнедеятельности. Он способствует будущим успехам студентов как в практической, так и в учебной деятельности.

Были проведены электронные опросы среди выпускников школ Миннесоты, учеников, студентов, учителей и родителей с целью определения их понимания понятия успеха.

На основе исследования авторы пришли к выводу, что такие умения, как способность к творчеству и получению информации оценены значительно выше, чем академические умения: сдача тестов, умение конспектировать и т. д. 